\title{
The Impacts of Tourism Development on the Archaeological Site of Petra and Local Communities in Surrounding Villages
}

\author{
Dr. Mairna Hussein Mustafa (Corresponding author) \\ Department of Sustainable Tourism Queen Rania Institute of Tourism and Heritage \\ The Hashemite University, P.O. Box 330127, Postal Code 13115, Zarqa, Jordan \\ Tel: 962-5-390-3333-5103E-mail: mairna@hu.edu.jo \\ Professor Sultan N. Abu Tayeh \\ Faculty of Business Administration, Department of Management, Taibah University \\ P.O. Box 344 al-Madina al-Munawwarah, Saudi Arabia \\ Tel: 966-4-846-0008Ｅ-mail: sultanabutayeh@yahoo.com
}

Received: March 8, $2011 \quad$ Accepted: April 20, $2011 \quad$ doi:10.5539/ass.v7n8p88

\begin{abstract}
This paper aims at exploring the different impacts of tourism development on the site of Petra in Jordan, also the perceptions of local community in Petra regarding these impacts. Although of the economic benefits gained by tourism, deterioration has been witnessed in this ancient city since damage to features of the archaeological site as well as adapting negative values by the local community took place. This paper sheds the light on these impacts, and presents some suggested implications to achieve a more sustainable tourism development in the site.
\end{abstract}

Keywords: Petra, Tourism impacts, Sustainable development, Bedul local community

\section{Introduction (About the Site and its Tourism Development)}

Since its rediscovery on August $22^{\text {nd }} 1812$ by the Swiss traveler J. Burckhardt, who disguised himself as a pilgrim seeking to make a sacrifice at the tomb of Aaron (Burckhardt 1822); explorers and tourists were attracted to the red rose city of Petra. The magnificent features of the city as well as the encounters with the traditional inhabitants of Petra (the Liyathnah and the Bedul) were recorded in the writings of several travelers (e.g. Doughty 1888; Musil 1907; Murray 1939), followed then by a significant number of books and scientific works of archaeologists who recorded the features and continuous discoveries in this ancient city (e.g. Harding 1959; Hammond 1973; Bowersock 1983; McKenzie 1987; Browning 1989; Joukowsky 1998) (Auge \& Dentzer 2006).

The great Nabataean capital and commercial center is carved in the red sandstone, Petra is located just outside the town of Wadi Musa in southern Jordan, with a distance of 260 kilometers from Amman via the Desert Highway and 280 kilometers via the King's Highway. The archaeological park which includes the ancient city is accessed through an outer Siq (path) in which significant features as Obelisk tombs and Djen Blocks can be seen, then a natural gorge known as Siq with a length of $1200 \mathrm{~m}$ with the water channels system is still existing, as well as niches and the two statutes of Dushara and al-Uzza gods. The Siq then widens upon the most magnificent of all Petra's monuments al-Khazneh (meaning Treasury in Arabic), which is carved out of solid rock with a height of $40 \mathrm{~m}$. the Siq continues through the ancient city were different features can be observed; these include the Street of Facades, the Amphitheater which can accommodate more than 6000 spectators, the Royal tombs (Urn Tomb, silk tomb, Corinthian Tomb and Palace Tomb), also the Mausoleum of Sextus Florentinius; that is in addition to the colonnaded street leading to triple-arched Temenos Gateway which marked the entrance into the courtyard or "temenos" of Qasr al-Bint, one of the main Nabataean temples in the city. Other remains include Nymphaeum, the Great Temple Complex, Temple of the Winged Lions, Petra Church, Blue Church, a number of high places (with their platforms for the purposes of giving animal sacrifices), al-Deir (the Monstery) with its huge façade (50 meters wide and 45 meters high), a big number of tombs as the Lion tomb, Garden Tomb, Tomb of the Roman Soldier, Triclinium (Feast Hall), as well as many other features (Map 1). In general, the remains of 
the city are dated to different periods within Hellenistic Period ( $2^{\text {nd }}$ century B.C.) to Late Byzantine Period (6 $6^{\text {th }}$ century A.D.) (Causle 2003; Teller 2006).

(Map 1 goes here)

Shoup (1985) is one of the very few references that gave a detailed history of tourism development in Petra; he mentions that the economic benefits of tourism to the city of Petra were recognized since the early decades of the $20^{\text {th }}$ century A.D. Before that, tourism in North Africa and Middle East was restricted by the Western imperialism that extended its influence over these regions, thus movement of travelers and tourists was mainly confined to the major cities and pilgrimage centers as Cairo and Jerusalem, traveling to Petra was difficult at that time, that area was still remote to many travelers, of who some could reach the city by horse or camel from either Jerusalem or Aqaba, bringing with them servants and guides with all necessary equipment since no facilities existed during that time; moreover, some hostility by local tribes against foreigners was recorded, this situation was to end when Transjordan government of Amir Abdullah extended its authority through the southern areas and ended raiding among the tribes, which resulted in more security, also the pavement of roads and the installation of electric and telephone lines. For Wadi Musa the nearest village to Petra, it was linked to the city of Ma'an by telephone in 1926. The first hotel in Petra was built in the early 1920's by Thomas Cook Travel Company near the Nabataean Temple of Qasr el-Bint, which became later in the 1940's known as Nazzal's Camp, this small hotel provided the visitors with simple comforts, for the Bedouins of the area, many of them were influenced by the West either through serving in the British-officered armed forces, being part of local workers in archaeological teams supervised by archaeologists from abroad, or by contact with European and American tourists. In the 1950's, the Jordanian government opened a rest house between Wadi Musa and Petra, members of the Liyathnah tribe living there were employed there and later were contracted to offer horses to transport tourists into Petra; moreover, they started to sell post cards, tour books, and souvenirs. On the other hand, the Bedul tribe who were living in Petra itself began to sell real and fake antiquities, post cards, and souvenirs, some of them could establish refreshments stands, and register their horses with the government as the Liyathnah did (Shoup, 1985). There was a conflict between the Bedul and the Liyathnah caused by tourist competition and differential access to education and market resources. The Bedul's involvement in tourism was traditional and stable; it was limited to selling souvenirs and refreshments besides providing guide services for extended trips, and a limited participation in the horse rental for tourists, which were actually dominated by the Liyathnah (Kooring and Simms 1996). When Petra was listed as a World Heritage Site in 1985, the Bedouin tribes who had settled in the area were forced to leave the caves they used as homes (Lubick 2004), even with the growth of tourism, the Bedul continued goat pastoralism and rainfall farming of wheat and barley, their residence included black tents of woven goat hair, numerous masonry structures in natural rock shelters, as well as empty Nabataean tombs, this residence took place in the area within and around Petra. Umm Siehoun was built as the village for the occupation the Bedul, providing better education and health care, but decreasing their access to traditional pastoral and agricultural lands and the cash economy of tourism, consequently, many of them refused to move out of the caves and rock shelters, more efforts were done by the Jordanian governments to move them by 1990 , only a very few tent camps remained in remote locations. A road to Petra from Umm Siehoun has re-established their access to tourists; the relocation process had also its negative consequences. The Bedul were concentrated in a very density settlement, their goat herding from the village increases the pressure on the already-depleted rangelands immediately around Petra, and so more people got involved in the tourist trade to compensate for economic losses in other areas and to support a growing population, many of these people realize the advantages of Umm Siehoun settlement, but they want to keep settling in their tribal lands and to have more involvement in tourism development (Kooring and Simms 1996).

The archaeological exploration, development and the management of the site were the responsibility of different establishments and stakeholders; some of these include: Ministry of Tourism and Antiquities, the Department of Antiquities, Petra Regional Authority, Local Governate of Petra, and Petra National Trust.

In the 1980's and 1990's, tourism and associated development has greatly increased in Petra, as well as the number of visitors to the site. According to the statistics of the Ministry of Tourism and Antiquities in Jordan (MOTA), the numbers of tourists visiting Petra kept increasing yearly on high rates, to start from 120,338 visitors in 1989 , to reach 766,938 tourists in 2009 , of which 105,582 were Jordanians, and 661,356 were from abroad. Table 1 shows the increase in the number of tourists during the period between 1989 and 2010 .

(Table 1 goes here)

Petra has been listed as a World Heritage Site in 1985, although of the great economic benefits gained by tourism to the site, the fact that great pressure and negative impacts caused by the increasing influxes of tourists 
since its discovery was not to be ignored by UNESCO, which considered it as an endangered site (UNESCO 1993). There are some potential economic, sociocultural and environmental negative impacts that are threatening the future of the site in the absence of a sustainable management plan for the site. This research aims at exploring these different tourism impacts through reviewing previous studies, also to understand the perceptions of local community about such impacts, therefore interviews were made with 48 individuals are who working inside the site of Petra.

\section{Tourism Impacts}

There are some potential economic, sociocultural and environmental impacts that are affecting the future of the site in the absence of a sustainable management plan for it. This paper is aiming at exploring these impacts, also suggesting implications to reduce negative effects caused by tourism development.

\subsection{Economic Impacts}

Tourism is considered as a main source of income to Jordan, according to the reports of Central Bank of Jordan (CBJ), this sector is contributing to the GDP with a percentage of $14 \%$ (2008). MOTA statistics shows that tourism receipts had reached 2067 million JD in the year 2009; while tourists' expenditures reached the value of 757.5 million JD for the same year. Part of tourists expenditure is characterized by entrance fees, 17,821,663 JD ( $1 \mathrm{JD}=1.4$ US \$) were the entrance fees for the year 2010 in Petra, which is $40 \%$ more compared to fees gained in 2009 , this site is contributing with $81 \%$ of total tourism sites entrance fees in Jordan (Jordan Press Foundation, 4/3/2011). The number of tourists who visited Jordan in 2009 was 7,084,552, of which 766,938 tourists were recorded for Petra, of them 229,782 tourists came by package tours.

Another economic impact is the increase in the number of tourism facilities and services; 38 accommodations of different types are existing in Petra, these are distributed as follows: 6 five stars hotels, 2 stars hotels, 7 three star hotels, 2 two star hotels, 8 one star hotels, 1 camp and 12 unclassified hotels. Moreover, tourists' nights in Petra's different accommodations were 577,888 nights (forming $25.3 \%$ share of tourist nights in Jordan), with 1.93 as an average length of stay. For occupancy rates of Petra accommodations, the statistical data of MOTA (2009) shows that 19,527 rooms with 36,622 beds are daily available, the monthly total reached 593,904 rooms with $1,113,839$ beds, the occupancy rate of these reached 233,923 rooms $(39.4 \%)$ with 446,969 beds $(40.1 \%)$. Tourism is considered as a main contributor to the economy of tribes living around Petra, 1,657 individuals of these tribes are employed in tourism services; these are distributed as follows: 1,088 in hotels, 118 in travel agencies, 31 in tourist restaurants, 18 in car renting offices, 59 in souvenirs shops, and 343 as horse guides.

\subsection{Environmental Impacts}

The main negative environmental impact taking place in Petra is characterized by the consequences of tourists' behavior while navigating in the site. The random climbing and movement on site's rock-cut features is leaving drastic effects. According to Tom Paradise, a geomorphologist from the University of Arkansas at Fayetteville, the fact that people are wearing shoes with soles that grab on everything instead of the rubber-soled working boots or soft sneakers, is causing the quick disappearance and loss of rock carved features; moreover, parts of the façade of the Khazneh [the Treasury] had lost sand because that's where tour guides let people sit, he indicates that this caused the loss of half a cubic meter of sandstone over a few years. Another threat facing Petra is the rising level of humidity resulted by the crowds of the tourists present at the site, which is an obstacle facing the preservation of sandstone. An indicator of deterioration is presence of the white deposits on the walls of carved tombs, mainly the Treasury; according to Paradise, tests showed that the deposits are to be of stearic acid, when people rest by leaning against the wall with sweating hands, they leave a scum of fat behind (Lubick 2004). He also monitored two areas in Petra within a 10 years period, the Khazneh and Theatre; finding that touching, leaning and rubbing the surface of Khazneh have receded the surface by $40 \mathrm{~mm}$ in less than 10 years, for the theater, markings of the stone masonry are continuously disappearing less than $5 \%$ of them can be seen now. One of the activities causing deterioration of site features is the "donkey rides", the hooves of these animals are causing erosion of sandstone, though, it can not be ignored that these are forming an important source of income to locals (PNT 2010). Horse and camel rides are also causing a problem to the site since the dust raised by these animals becomes encrusted on the sides of the Siq. The locals themselves are negatively affecting the site by some of their behaviors, the stalls selling souvenirs and refreshments to the tourists are many in numbers, and rudimentary in a way that disturbs the harmony of the site (UNESCO 1993). Some of the locals in Petra used to break apart the sandstone from the site to grind it and fill sand bottles with it, these sand bottles are one of the distinguished souvenirs sold to tourists (PNT 2010). Some graffiti is also to be seen on the rock cut Siq and tombs of the city. Some littering can also be noticed although of the littering cans placed throughout the site. Another significant issue to be considered is the uncontrolled urban development around the site. The area 
adjacent to the site is full at present with hotels and residential units, an area that was not fully survey or excavated by the archaeologists, there is a possibility that more remains of the ancient site are to be uncovered in the area stretching from the existing site up to and including parts of the village of Wadi Musa (UNESCO 1993). The authors could notice that the areas surrounding three, two, and one star rated hotels are neglected, such areas are used for dumping old furniture and material used in hotels. In addition to the danger caused by tourists and tourism development, other natural factors are negatively affecting the site; one of these is the corrosion of lower sections of facades by the wind which carries sand particles from the crumbling sandstone rock. Also, the water that infiltrates into the rock by capillary action enables vegetation to grow in the interstices, consequently resulting in the fracture of rock, and in worse cases rock fall (UNESCO 1993).

\subsection{Socio-cultural Impacts}

Commercialization of Bedouin culture was one of the results caused by the great interest of tourists in Petra region; this was to affect booth Bedul tribe in Petra as well as 'Ammarin tribe in Baidah $(5 \mathrm{~km}$ to the north of Petra), tribesmen were aware of the tourist appeal of the traditional Bedouin tent, and so they started to set their own camps where they built refreshments stands, women also started to sell different Bedouin items to tourists. Another impact is seen in the change of values, the young Bedul try to imitate Westerners in dress and manners, though, these Westerners are seen as corrupt with negative values as alcoholism and illegal relationships, which indicates a kind of confusion over the values of the West and the strengths of ties to Bedouin culture by some of the locals. A cultural change that took place after expansion of tourism development can be seen clearly in the decline in traditional handicrafts, since the 1950's, few women have woven carpets or even their own tents, tourists' interest in the in such items helped in the revival of these arts, consequently, some women started to make small bags, carpets, miniature looms with partially finished panels still on them, and spindle whorls in order to help in supporting their families (Shoup, 1985).

Some other negative impacts are characterized by child labor since many children are dropping out of school to work in tourism, unfortunately, such impact is to be perceived as a positive one by most of the locals, the different languages and working skills learnt by these children as well as gaining money are tempting many of them to consider work in tourism as vendors and horse guides much more important than getting education at schools. Also, sexual relationships by local adults with tourists, though, there are some long lasting marriage relationships (one of the most famous marriage stories was the one of Marguerite van Geldermalsen, a tourist from New Zealand who came to Petra in 1978, at that time she met Mohammad Abdullah, a local from Petra, they got married and had 3 children, she was widowed in 2002 and then moved to Sydney, she published her story in her famous book "Married to a Bedouin" in 2006). There are some positive cultural impacts of tourism on Petra's local community as financing the education of local residents; learning foreign languages by them and influencing the interaction of locals with their own society (Hijazeen 2007).

\section{Local and International Efforts to Reduce Negative Tourism Impacts in Petra}

As a reaction to the rapid growth of tourism in Petra, consequently, the increase of different negative impacts that took place by such development, the Jordanian government invited some international institutions to prepare management plans for the site. Though, as stated by Akrawi (2000), such plans are still not implemented nor endorsed by authorities. One of these plans is the US National Parks Service (NPS) "Master Plan for the Protection \& Use of the Petra National Park" in 1968, the plan focused the establishment of a National Park with an independent park division and zoning, the plan also focused on the tourism development, archaeological protection and preservation, social issues and administrative issues. One of the main recommendations of this plan is the rehabilitation of the Nabataean hydraulic system to protect the antiquities and to reduce the damage caused by flash floods. The social dimension aspect is addressed by recommending that the Bidul tribe of Petra be relocated to a location outside the archaeological site to preserve its resources with providing the community with agricultural lands to maintain their livelihood. Another plan is the UNESCO "Petra National Park Management Plan" put in 1994, the plan focused on the different kinds of threats in the site, and suggested recommendations and proposals to remedy these threats. These included zoning, archaeological conservation, and conservation of biodiversity, Park infrastructure and personnel, physical planning, sustainable rural development, mitigation measures, training and communication, research and monitoring, and the implementation of the Management Plan. In 1996, US/ICOMOS "Management Analysis \& Recommendations for the Petra World Heritage Site" plan was developed; this plan addressed the maintenance of the management values related to infrastructure in Petra. The US National Parks Service "Operating Plan" in 2000 is distinguished by its comprehensive management policies, detailed operating procedures and standards, a training plan, and the recommended position of the Petra Archaeological Park (PAP) within the organization of the Ministry of Tourism and Antiquities (MOTA). Although of focusing on some issues related to local residents of 
Petra in these plans, as those of relocation and rural development, the aspect of their perceptions toward tourism development was not one of the basic topics to be addressed, a fact that initiates the need to focus on the perceived benefits and problems caused by the tourism to these residents, also capacity building that involves them and all other stakeholders. The growth of tourism in any area or region cannot be achieved without the support of its residents; consequently, the issue of perceived impacts of tourism was to have its significance in empirical literature since 1970's (Ap \& Crompton 1989). Directing tourism growth toward local needs, interests, and limits can greatly enhance its value to the community, and help create a sustainable industry of a significant economic value that will affect the lives of local residents; on the other hand, their attitudes and behavior can clearly influence the satisfaction and overall experience of tourists (WTO \& UNEP 2005).

In this research, the results of interviews that were made with 48 locals working at the site of Petra were presented; these interviews aimed at understanding the perceptions of these individuals about different impacts of tourism.

\section{Understanding the Perceptions of Local Community of Petra about Tourism Impacts}

The 48 individuals were interviewed by the first researcher and students of Tourism Department/ Hashemite University for between 30-50 minutes. All the interviews were written on designated form that included 19 questions about possible impacts that have occurred after tourism development, the answers were then written into reports, each report focused on a specific question. These reports were read by the first researcher and then were translated into English and were put in 3 category headings that were generated from the data, these were for the 3 types of impacts: economic, environmental and sociocultural. It should be mentioned that respondents were not completely willing to give detailed answers particularly for economic and environmental impacts, though they were more open to express their perceptions about sociocultural impacts of tourism.

44 males and 4 females responded to the interviewers, of these 4 were 20 or less years old, 27 were 21 to 30 years old, 9 were 31 to 40 years old 1 was 42 years old, 7 respondents did not give their ages. Of the 48 respondents, 13 had their elementary education, 24 finished high school, 1 had a community college degree, 8 had a Bachelor degree, and 1 had got a post graduate degree.

In general, the positive economic impact of tourism was perceived by most of the respondents, 45 of them mentioned that tourism helped in generating income and job opportunities for the local community. Though, some negative economic impacts were to be perceived as well, 47 of the respondents agreed that tourism contributed to the increase in the price of lands and properties, a respondent stated:

Yes, this can be widely seen because of the big number of investors in the region, of which some are from abroad.

Another said:

The wide spread of hotels and restaurants in Petra played a significant role in increasing the price of lands.

Another negative impact to be perceived was the lack of services and amenities inside the site; one of the respondents said:

The contribution of tourism cannot be seen since the income generated by the tourism is not used in enhancing these services and facilities.

Another respondent mentioned that improving amenities inside the site was for the benefit of tourists not the locals.

For environmental impacts; it was noted that most of the respondents agreed that tourism contributed to increasing environmental awareness among locals of Petra and its surrounding regions. They also said that most international tourists have a positive behavior if compared to domestic tourists. For those who did not agree, they had some valuable comments regarding this aspect; one said:

No contribution is seen since either awareness programs nor does environmental signage exist at the site.

Some respondents suggested that more trash bins and signage should be placed at the site; also awareness campaigns should be continuously conducted. For the contribution of tourism to increasing environmental pollution, half of the respondents agreed about this, they said that littering is a major problem that is facing the site, also touching monuments' facades by tourists, especially during the high seasons. For those who disagreed, they said that management of the site is providing it with a sufficient number of cleaning staff. 41 of the 
respondents agreed that tourism had a great influence on preserving the archaeological site and conserving its monuments through revenues of tourism, though, there were some comments from some of the respondents that more efforts should be done. One said:

Yes, sure... but most of these conservation works are by foreign centers, the ones by Jordanian formal bodies are so limited.

Another commented that most of conservation is taking place in the Treasury and Museum areas, some of these respondents are hoping for more efforts to enhance the cleanliness and conservation of the site.

Regarding the sociocultural impacts of tourism; these composed the majority of questions in the interviews. 30 respondents agreed that tourism contributed to the strengthening of social bonds among locals, many of these respondents mentioned that this comes in the form of commercial collaboration between the small businesses inside the site, especially those selling souvenirs to tourists. For those who disagreed, one said:

Working in tourism does not leave time to give concern to such issue.

Another said:

Tourism has caused that many parents leave their families for long periods of time.

It was noticed that 22 of the respondents agreed on the fact that tourism contributed to family disruption, but not to the increase in cases of divorce; they justify that by the willingness of some male members in the family to have girlfriends (mainly from American and European tourists). 45 of the locals in the sample agreed that tourism contributed to increase the number of marriages between locals and foreigners; they mentioned that this applies only to males in this society, some of them gave the example of Marguerite van Geldermalsen (Um Rami) (mentioned previously in the sociocultural impact section); they also stated that many of these marriages are between local men and tourist women particularly from New Zealand, Switzerland, Australia and Italy. Some said:

Many of these young men get married from tourists for immigration or getting job opportunity abroad.

The individuals of the sample were asked if tourism has any role in creating friendship relations between tourists and locals; 46 of them agreed, but some of them stated that tour guides are more to have such friendship, others mentioned that this helped in having repeated visits by these tourists. Another potential impact that respondents were asked about was the contribution of tourism to enhancing the knowledge of local communities, most respondents said that such knowledge was in languages spoken by tourists, few of them stated that knowledge about history and antiquities of the site was mainly acquainted for answering the questions of tourists.

A question in the interview was if tourism helped in the spread of negative values and behaviors in the local community of Petra; few respondents said that such Bedouin society stick to its own conservative values, the majority of respondents had an opposite point of view, one stated:

$$
\text { Yes, tourists have different values that are different from ours }
$$

Another said:

Yes, alcohol drinking and illegal relationships, that's all because of having no awareness

Some others mentioned that underage drinking and having girlfriends (usually from tourists) were all things that came with tourism. Some individuals mentioned changes in the appearance, one of the respondents replied:

$$
\text { Partially, it can be seen in tearing Jeans and wear fashion }
$$

Another said:

There is a negative effect; some of the locals in Petra are imitating these tourists by wearing earrings and having their hair longer with being braided.

It should be mentioned here that most of respondents confirmed that such negative values are only seen among males, mainly those working at the site, they also consider such group as a minority. Though, few respondents thought that wearing modern fashion clothes is not necessarily an imitation as much as coping with the present.

The respondents were asked if tourism is encouraging kids from local communities to dismiss their schools so that they can work in tourism; most of the respondents agreed saying that it's all for financial reasons, they see it 
as a positive thing since these kids are learning several languages and that tourism help them in supporting their families, in addition to making them skillful in the work of tourism. Few of them said that such phenomenon is due to lack of awareness. A respondent said:

Yes, especially among those living in Um Saihoun... their kids are at the site during the whole day, they speak so many languages and work as horse guides.

Finally, the respondents were asked if tourism contributed to sustaining local handicrafts and arts; the majority said that this is very limited, although there is willingness of tourists to buy mosaics, monuments depicting Petra and ornaments taking the shape of the Nabataean god Dushara. A respondent stated:

It is supposed to, but it has really a very minimal contribution, instead of importing souvenirs from India and Pakistan, we hope to have more centers to make local souvenir pieces.

Another commented:

Yes, but unfortunately... most of the handcrafted pieces are from abroad, like those from India and Turkey, I have a shop where $95 \%$ of the sold material is not locally made.

\section{Discussion and Conclusion}

In general, local empowerment became one of the basic aims of sustainable tourism, it is based on engaging local communities in planning and decision making about the management and future development of tourism in their area, in consultation with other stakeholders (WTO \& UNEP 2005). Recognizing the needs of local community in Petra becomes then vital to create a better tourist experience; none of the previously mentioned management plans concentrated on locals attitudes and perceptions toward tourism, especially those who were replaced in Umm Siehoun settlement and then their agricultural and herding activities, which makes then negative attitudes toward tourism development and investments from outside by the local community possible to a great extent although of the benefits gained already by them.

Environmentally, conservation and development projects view local people's support for protected areas management as an important element of biodiversity conservation. Finding common goals between conservation of resources and the development needs of local people is an essential part of understanding sustainable protected areas management (Dolisca et al 2007). This initiates the need to establish more comprehensive plans that involve such aspects. According to WTO \& UNEP (2005), some policy areas if taken into account would be the approach to achieve sustainability in tourism development (which can be applied to the case of Petra); one of these is maximizing the contribution of tourism to the economic prosperity of the host destination by supporting locally owned businesses, especially those of handmade crafts; the competition between the Jordanian product and the imported crafts is a major problem that can be witnessed; the several stores and stands within and around the site sell imported pieces in bulk from India, Pakistan, Egypt, China, or other Middle East countries. For example: pashmina shawls and scarves, inexpensive rayon and cotton dresses from India, cheap shells, jewelry, clothing and toys from China; and Jewelry from Yemen. There is an unfair competitiveness of local products against imported souvenirs which are present in more quantities; also these are to be sold with lower prices if compared to local ones (Akhal et al 2008), encouraging and supporting local production of handicrafts would be a policy area that should be taken into concern.

Respecting and enhancing the historic heritage, authentic culture, traditions and distinctiveness of host communities, with maintaining and enhancing the quality of landscapes, both urban and rural, and avoiding the physical and visual degradation of the environment are also to be considered. Spreading awareness among tourists to reduce their negative behavior (mainly wear and tear) should be done through supplying the different parts of the site with interpretational methods that focus on behavioral aspects, also conducting programs for this purpose. Although some individuals of the local community are already involved in archaeological excavations and conservation; it is important to make the community aware of the negative consequences related to their activities at the site, such as herding goats, illicit excavations, and the inappropriate spatial characteristics of shops and stands located around and inside archaeological sites. Many of the stands located inside the archaeological site are made of materials that do not fit the appearance of the site (plastic sheets covering wooden beams and roofs to create a shelter), most of these materials are also in a bad condition (torn cloth and spotted wood boards); another serious issue is the littering caused by the trash thrown by workers of these shops in nearby areas. Awareness should also be concerning some social problems as illegal relationships and child 
labor. For tourists, it becomes important to educate guides (who will then inform the tourists) about appropriate behavior in the archaeological sites.

\section{References}

Akhal, R., Shabaneh, A. \& Tyroler, C. (2008). Handicraft Sector in Aqaba: Diagnostic, Strategy and Action Plan Development, Program, Aqaba Community and Economic Development (ACED) Program -iv, United States Agency for International Development USAID, [Online] Available: http://www.aced-jordan.com/files/publication_attachments/Handicraft $\% 20$ Sector $\% 20$ in $\% 20$ Aqaba $\% 20 \% \mathrm{e} 2 \% 80$ \%93\%20Diagnostic,\%20Strategy\%20and\%20Action\%20Plan(publish).pdf (January 6, 2011)

Akrawi, A. (2000). Summary from International Workshop organized by the Getty Conservation Institute and Loyola Mary Mount University, Corinth, Greece, May 2000, In J. M. Teutonico \& G. Palumbo (Eds.), Management Planning for Archaeological Sites. [Online] Available: http://cool.conservation-us.org/jaic/articles/jaic43-03-005_indx.html (April 21, 2011)

Ap, J. and Crompton, J. L. (1998). Developing and Testing a Tourism Impact Scale. Journal of Travel Research, 32(1):47-50. [Online] Available: http://dx.doi.org/10.1177/004728759803700203

Auge, Ch. \& Dentzer, J. (2006). Petra: The Red Rose City, New Horizons. London: Thames \& Hudson Ltd.

Burckhardt, J. (1822). Travels in Syria and the Holy Land. [Online] Available: http://www.fullbooks.com/Travels-in-Syria-and-the-Holy-Land1.html (October 20, 2010)

Causle, F. (2003). Art and History of Jordan. Florence: Casa Editrice Bonechi.

Dolisca, F., McDaniel, J., \& Teeter, L. (2007). Farmers' perceptions towards forests: A case study from Haiti. Forest Policy and Economics, 9:704-712. doi:10.1016/j.forpol.2006.07.001, http://dx.doi.org/10.1016/j.forpol.2006.07.001

Hejazeen, E. G. (2007). Tourism and Local Communities in Jordan: Perception, Attitudes and Impacts: "a Case Study on Five Archaeological Tourist Sites". München: Tourism Studies, University of Eichstätt-Ingolstadt.

Jordan Press Foundation. (2011). 2,423,000,000 JD as Tourism Income during Last Year with an Increase of 17\% Compared to 2009, March 4. [Online] Available: http://www.alrai.com/print.php?news_id=380084 (March $8,2011)$

Kooring, D. \& Simms, S. (1996). The Bedul Bedouin of Petra, Jordan: Traditions: Tourism and an Uncertain Future. Cultural Survival Quarterly, Issue 19, 4. [Online] Available: $\mathrm{http} / /$ www.culturalsurvival.org/ourpublications/csq/article/the-bedul-bedouin-petra-jordan-traditions-tourism-an d-uncertain-future (December 21, 2010)

Liu, J. \& Var, T. (1986). Resident Attitudes toward Tourism Impacts in Hawaii. Annals of Tourism Research, 13(2):193-214. [Online] Available: http://dx.doi.org/10.1016/0160-7383(86)90037-X

Lubick, N. (2004). Petra: An Eroding Ancient City. Geotimes, Issue June 2004. [Online] Available: http://www.geotimes.org/june04/feature_petra.html (December 21, 2010)

MOTA. (2010). Statistical Bulletin of 2010, published by Department of Statistics in the Ministry of Tourism and Antiquities. [Online] Available: http://www.tourism.jo/ar/Default.aspx?tabid=120 (April 20, 2011)

Petra National Trust. (2011). A Map of Petra. [Online] Available: http://petranationaltrust.org.tmp2.secure-xp.net/ui/ShowContent.aspx?ContentId=75 (March 7, 2011)

Ross, G. (1992). Resident Perceptions of the Impact of Tourism on an Australian City. Journal of Travel Research, 30(3):13-17. [Online] Available: http://dx.doi.org/10.1177/004728759203000302

Shoup, J. (1985). The Impact of Tourism on the Bedouin of Petra. The Middle East Journal, 39(2):277-291.

Teller, M. (2006). The Rough Guide to Jordan. New York: Rough Guides.

UNESCO. (1993). A Plan for Safeguarding Petra and its Surroundings; published in the World Heritage Newsletter, issue No. 2, June 1993. [Online] Available: http://nabataea.net/ppark.html (December 21, 2010)

WTO \& UNEP. (2005). Making Tourism More Sustainable: A Guide for Policy Makers. World Tourism Organization and United Nations Environmental Program. 
Table 1. Numbers of Visitors to the site of Petra (1989- 2010) (MOTA 2010, http://www.tourism.jo/ar/Default.aspx?tabid=120)

\begin{tabular}{|c|c|}
\hline Year & Number of Visitors \\
\hline 1989 & 120,338 \\
\hline 1990 & 102,151 \\
\hline 1991 & 40,889 \\
\hline 1992 & 117,347 \\
\hline 1993 & 138,559 \\
\hline 1994 & 200,505 \\
\hline 1995 & 337,221 \\
\hline 1996 & 414,448 \\
\hline 1997 & 380,527 \\
\hline 1998 & 347,109 \\
\hline 1999 & 429,644 \\
\hline 2000 & 481,198 \\
\hline 2001 & 231,203 \\
\hline 2002 & 158,837 \\
\hline 2003 & 160,658 \\
\hline 2004 & 310,271 \\
\hline 2005 & 393,186 \\
\hline 2006 & 359,366 \\
\hline 2007 & 581,145 \\
\hline 2008 & 813,267 \\
\hline 2009 & 766,938 \\
\hline 2010 & 975,285 \\
\hline
\end{tabular}

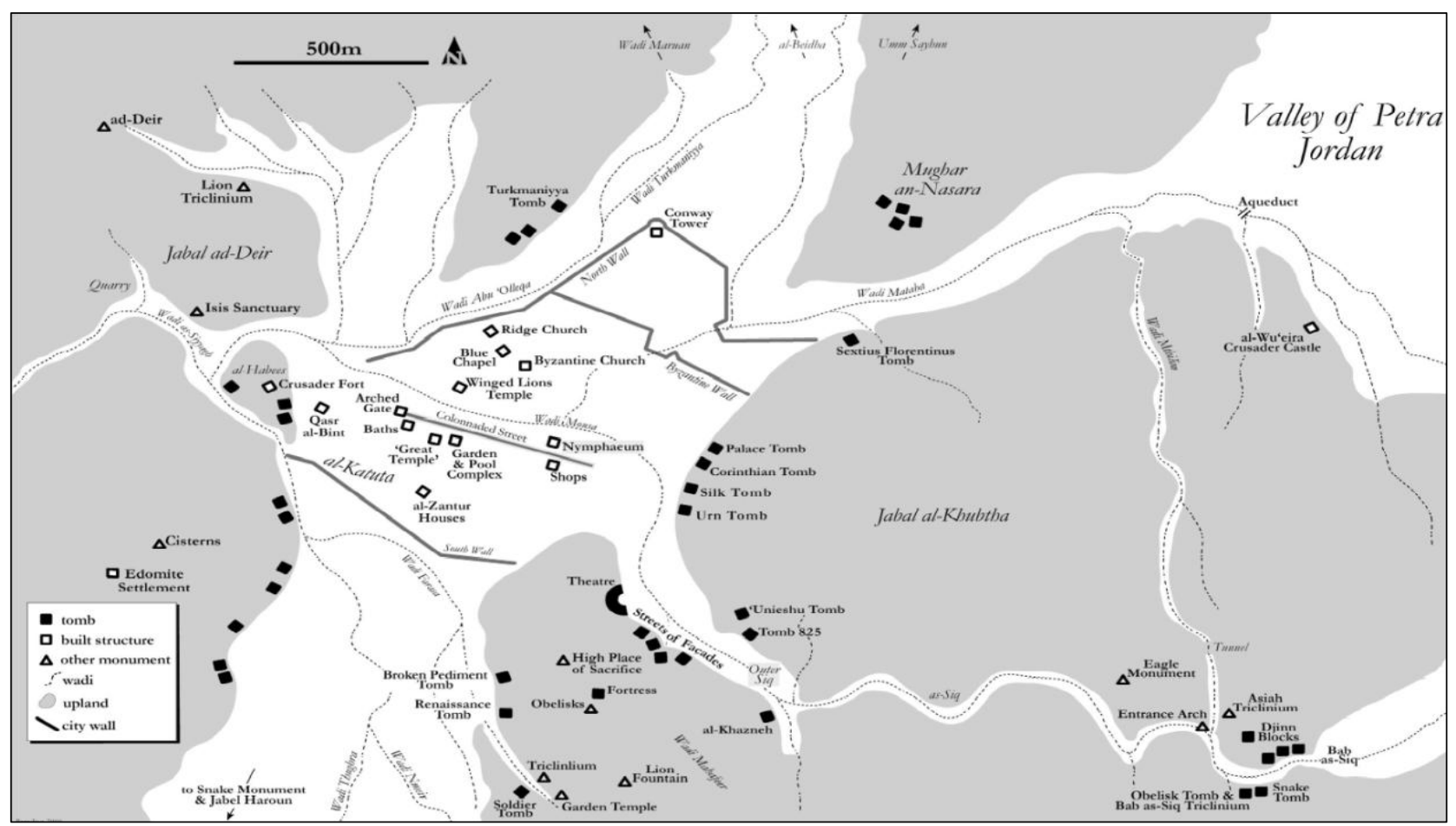

Map 1. A map showing the locations of different archaeological features of Petra (Petra National Trust 2011) 